\title{
Eutrophication and mussel culture in the western Dutch Wadden Sea: impact on the benthic ecosystem; a hypothesis*+
}

\author{
Henk W. van der Veer \\ Netherlands Institute for Sea Research; P. O. Box 59, 1790 AB Den Burg Texel, \\ The Netherlands
}

\begin{abstract}
Since 1950, two large-scale changes have taken place in the western Dutch Wadden Sea, namely the eutrophication of the area and the introduction of an extensive mussel culture. Although eutrophication in the fresh waters started already around 1950, nutrient concentrations in the western Wadden Sea remained fairly constant until about 1970, due to the retention of nutrients in Lake IJssel, the main source. From 1970-1980 concentrations increased strongly, and during the last years the situation has stabilized. Mussel culture was introduced in 1950 and expanded during the next decade to an area of $70 \mathrm{~km}^{2}$, all situated in the sublittoral area. From 1960 the area of mussel culture remained about constant with fluctuating yields of between 35 and 120 millions of $\mathrm{kg}$ fresh weight. Due to a lack of data for the period until 1970 the impact of eutrophication and mussel culture on the ecosystem cannot be assessed. From 1970 onwards an increased biomass and production of the macrofauna in the intertidal zone has been observed, which is attributed to eutrophication. The hypothesis is postulated that the introduction of mussel culture between 1950 and 1960 has resulted in an increased food competition in the area, leading to a decreased stock of the macrofauna in the intertidal. Eutrophication from about 1970 onwards has improved the food conditions and as a result both the macrofauna in the intertidal and the mussel in the sublittoral area would have increased in biomass, allowing higher maximum yields of the mussel culture. The importance of monitoring programs is stressed to follow these trends in the near future and to check the above hypothesis in areas where it is decided to introduce or intensify mussel culture.
\end{abstract}

\section{INTRODUCTION}

The Wadden Sea is an important area as nursery for a number of commercially important fish species (Zijlstra, 1972) and as resting and breeding area for a number of bird species (Smit \& Wolff, 1983). To fulfill the food requirements of all these species, the benthic macrofaunal assemblages in particular form an important component. Fluctuations in these food items might directly affect growth and survival of the fish and bird species.

Time series on the intertidal macrofaunal biomass are available from about 1970 onwards (i.e. Beukema \& Cadée, 1986), indicating the naturally occurring variations in

* Presented at the VI International Wadden Sea Symposium (Biologische Anstalt Helgoland, Wattenmeerstation Sylt, D-2282 List, FRG, 1-4 November 1988)

+ Publication No. 30 of the project "Ecological Research of the North Sea and Wadden Sea" (EON) 
biomass due to fluctuations in the abiotic environment, such as the seasons and cold winters (Beukema, 1974, 1979, 1985; Beukema \& Essink, 1986). However, on a longer time scale some gradual changes have taken place in the area. From 1950 onwards, the nutrient input in the area has increased due to higher concentrations in the fresh water run-off from the mainland (van Bennekom et al., 1975; van der Veer et al., 1989). An extensive mussel culture has been introduced in the western Dutch Wadden Sea from 1950 onwards with annual yields of more than 100 millions $\mathrm{kg}$ fresh weight. Although an eutrophication effect on the benthic intertidal community was suggested to occur from about 1970 onwards (Beukema \& Cadée, 1986), an overall hypothesis about the combined effect of eutrophication and mussel culture is lacking at present, mainly due to the absence of data over the period 1950-1970.

Since plans have been developed to intensify mussel culture both in the Dutch and German Wadden Sea, an attempt is made in this paper to come to such a hypothesis for the western Dutch Wadden Sea, although hardly any data are available for direct proof. Support for this hypothesis might arise in the near future, if each extension of mussel culture is properly accompanied by a monitoring program.

\section{EUTROPHICATION}

Eutrophication of the Wadden Sea, defined as an enrichment with nutrients and/or organic matter, occurs by import of material from the mainland by fresh water discharges and from the North Sea. The main nutrient load of the area results from fresh water discharges from Lake IJssel, an artificial lake supplied by the river IJssel, a branch of the river Rhine. Import from the North Sea is restricted to the exchange of water between the Wadden Sea and the coastal zone of the North Sed through the tidal inlets. On the average about $5-10 \%$ of the water mass entering the Wadden Sea through the tidal inlets consists of fresh water from the river Rhine (van Bennekom et al, 1974; Zimmerman, 1976), transported along the coast by the residual currents from Hook of Holland to the Wadden Sea.

All data concerning eutrophication have been taken from van der Veer et al. (1989). Eutrophication of the main source, the river Rhine, shows a consistent increasing trend from 1955-1980, both for $P$ and $N$. The same increase in nutrient load is present in the inflow of river IJssel in Lake IJssel near Kampen for the period 1959-1985, although the amount is reduced by an order of $5-6$, caused by the lower water discharge of the river IJssel.

The nutrient load of the fresh water discharge from Lake IJssel into the Wadden Sea showed a different pattern compared with the trends in the river Rhine and IJssel. In contrast to the increase in the river IJssel from 1959 onwards, values of the discharge of Lake IJssel remained fairly constant from 1950 until 1970. After 1970 both total-P and total- $\mathrm{N}$ increased 2-3 times until 1985. Compared with the inflow, the concentrations in the outflow show a time lag of about 20 years with respect to the start of the eutrophication of Lake IJssel. A large part of particulate P and $\mathrm{N}$ settled in the basin of Lake IJssel at the river inflow near Kampen and was adsorbed by the bottom (de Wit et al., 1982; Postma, 1985). With increasing eutrophication the adsorbtion capacity of the lake was reached and increasing concentrations near the sluices were found. As a result, during the last few years the retention of total-P and total- $\mathrm{N}$ by the lake will have decreased. 
In the western Wadden Sea the increase of $\mathrm{P}$ components seemed to be much larger than that of $\mathrm{N}$ components. A main part of the increase in nutrient concentrations took place between about 1970 and 1980 . During the last few years concentrations seemed to drop somewhat. Between 1950 and 1980 total-P increased by a factor of 3-6, depending on the season. For total-N, the increase was much less. The same trends could be observed in the Vliestroom basin. For more details and data, see van der Veer et al., 1989.

\section{MUSSEL CULTURE}

\section{Life history of the mussel}

The blue mussel (Mytilus edulis L.) is one of the most common invertebrates in the Wadden Sea (Beukema, 1974; Dekker, 1987). Spawning occurs from March onwards, and after fertilization of the eggs in the water, it takes about one month before the hatched larvae settle for the first time at a length of $200 \mu$ on all kinds of hydroids and sand tubes of the worm Lanice (Maas Geesteranus, 1942).

During their whole life cycle, redistribution by pelagic transport remains an important mechanism, although its importance decreases with increasing size. This detaching, transport and attaching is passed through at least a few times in succession. Even mussels of $5 \mathrm{~cm}$ with an age of at least one year have been found transported by currents (Kuenen, 1942; Maas Geesteranus, 1942).

Growth of young mussels depends on temperature and on amount and availability of food. Under optimal conditions, mussels can attain a size of about $7 \mathrm{~cm}$ during their first year, as was observed in former times in the open harbour of Den Helder (Swennen, pers. comm.). Normally, mussels of this size will differ in age up to and over 6-7 years.

Although mussels can be found in the whole Wadden Sea area, their distribution is very patchy, in small or large beds in which animals accumulate. Mussels are numerous in the intertidal zone, mainly in patches along the borders of creeks and across the drainage channels of large shallows (Verweij, 1952). The highest part of the intertidal zone is generally hardly inhabited mainly because of shortage of food (Kuenen, 1942). Mussels are also found in the sublittoral area or even in deeper tidal channels (Dankers, 1986; Dekker, 1987), although in these areas they are heavily predated, by crabs and starfish in particular.

The large filtering activity of mussels results in an enormous production of faeces and pseudofaeces. A great amount of this material settles between the mussels and after some time they may be covered by their own faecal products. In the course of a season, mussel beds grow on their own faeces and an elevation of some tens of $\mathrm{cm}$ can be reached during a season. Mussel beds form an excellent hard substrate for new settlement of mussel brood, which can suffocate the older ones. In a mussel bed, large variations in food availability are present between the individual mussels, depending on their position, and as a result large differences in growth rate can be found.

Most of the mussel beds are at least partly destroyed by wave action in autumn or by ice during severe winters. In old mussel beds individual mussels with an age of 6-7 years can occur, but it is thought that normally most mussel beds have disappeared in the Wadden Sea within 3-4 years (Verweij, 1952).

Two main groups of predators on mussels are birds and starfish, whereby predation 
by the starfish Asterias rubens will be mainly restricted to the deeper subtidal parts of the Wadden Sea. Another important mortality factor is fisheries by man on wild musselbanks, either as food for human consumption, for seeding on culture plots, or as food for duckfarms, as occurred in the Dutch Wadden Sea until about 1950.

\section{Culture}

Although exploitation of shellfish by fishing of wild banks is as old as the Wadden Sea itself, commercial mussel culture on selected plots in the Dutch Wadden Sea started during the second world war as a reaction to the shortage of food. However, before most culture plots had become productive, the war had ended and the demand for mussels stopped (Havinga, 1960).

Reintroduction of mussel culture in the Dutch Wadden Sea took place in the tidal basin of the Lauwers after a disaster among the cultured mussels in the estuarine delta area in 1949 caused by infection by a parasite, the copepod Mytilicola intestinalis. In the eastern Wadden Sea this parasite was absent and as a consequence mussel culture was started. These mussel plots were transferred to the western part some years later, when the parasite also appeared in the German and eastern part of the Dutch Wadden Sea. As a consequence of a flood in the Delta area in 1953, it was decided to close a number of tidal inlets in the Delta area by dams. The resulting loss of area for mussel culture was compensated for by the introduction of new beds in the Wadden Sea (Havinga, 1960). From the fifties onwards, the total area of culture lots steadily increased from $10 \mathrm{~km}^{2}$ in $1951 \mathrm{up}$ to about $70 \mathrm{~km}^{2}$ in 1960 . No further extension has occurred since 1960 (Fig. 1). The same holds for the number of plots (Fig. 2).

Mussel culture shows a strong seasonal pattern of 'activity. During a short period in spring, farmers are allowed to collect mussel seed - spat at a size of a few $\mathrm{cm}$-, from wild banks. Between 1984 and 1987, this fishery varied between 74 and 113 millions of $\mathrm{kg}$ per

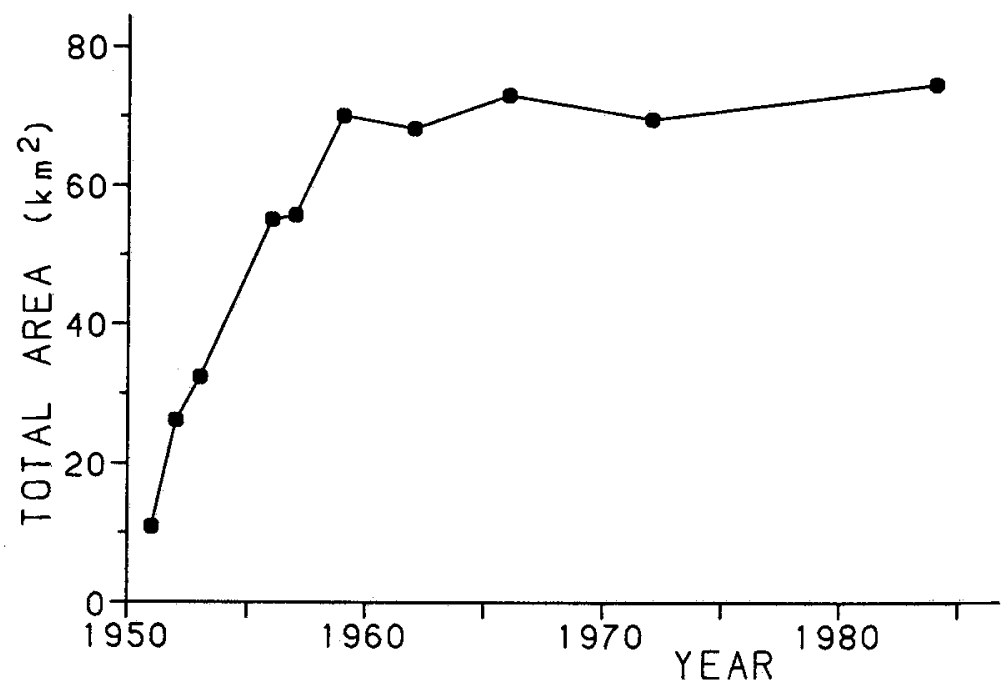

Fig. 1. Total area of mussel culture plots $\left(\mathrm{km}^{2}\right)$ in the western Dutch Wadden Sea from 1950 onwards, based on information from "Direktie van de Visserijen" 


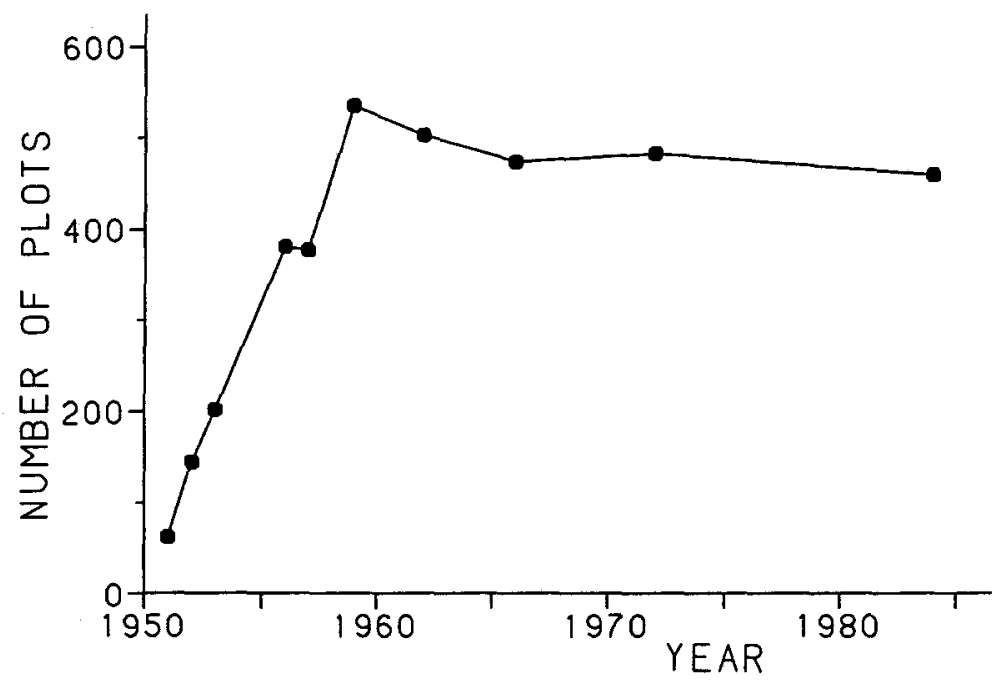

Fig. 2. Number of mussel culture plots in the western Dutch Wadden Sea from 1950 onwards, based on information from "Direktie van de Visserijen"

year (Dankers et al., 1986, 1988). Most of this mussel seed is spread out on the musselbeds, which are situated in the sublittoral zone of the Wadden Sea (Fig. 3). A small part of the seed is used for musselbeds in the Delta area. After introduction, the mussels grow to medium size during their first year. The culture plots are regularly cleaned of starfish by the farmers by fishing and redistribution of mussels on the beds. During the next year, mussels reach consumption size and most of them are harvested and transported to the Delta area, where cleaning of the mussels occurs in special areas. As a result, the culture plots can be divided into plots where seed is stored, areas where middle size mussels are cultured and plots with consumption mussels. This subdivision largely depends on the quality of the plots which is the result of variation in abiotic and biotic conditions.

Due to the introduction of mussel culture in the western Wadden Sea, Mytilus edulis is nowadays one of the most abundant species in the subtidal area, both in and outside the culture plots (Dekker, 1987). Outside plots the biomass of mussels amounts to about $8.3 \mathrm{~g} \cdot \mathrm{m}^{-2}$ AFDW (ash free dry weight), which is about $38 \%$ of the total biomass present. On culture lots, the number and biomass of mussels is significantly higher; as a mean, about $250 \mathrm{~g} \mathrm{AFDW} \mathrm{m}^{-2}$ can be found. The total yield of consumption mussels shows large fluctuations over the years and is strongly influenced by environmental circumstances (storms etc.) and by the market price. At present, the annual yield amounts to a mean of about 80 millions of $\mathrm{kg}$ fresh weight (Fig. 4).

Mean production of the mussel culture can be estimated for the years 1981-1982, based on the benthic survey carried out by Dekker (1987). In 1981-1982 the yield of consumption mussels amounted to some 90 millions of $\mathrm{kg}$ (Fig.4). Assuming a mean AFDW of $5 \%$ of the fresh weight, including shells (Dankers, 1986), this means a production of 4.5 millions of $\mathrm{kg}$ AFDW. Related to the total biomass on the plots in 1981-1982 of $250 \mathrm{~g} \mathrm{~m}^{-2}$ (Dekker, 1987) or in total 17.5 millions of $\mathrm{kg}$ AFDW (assuming a 


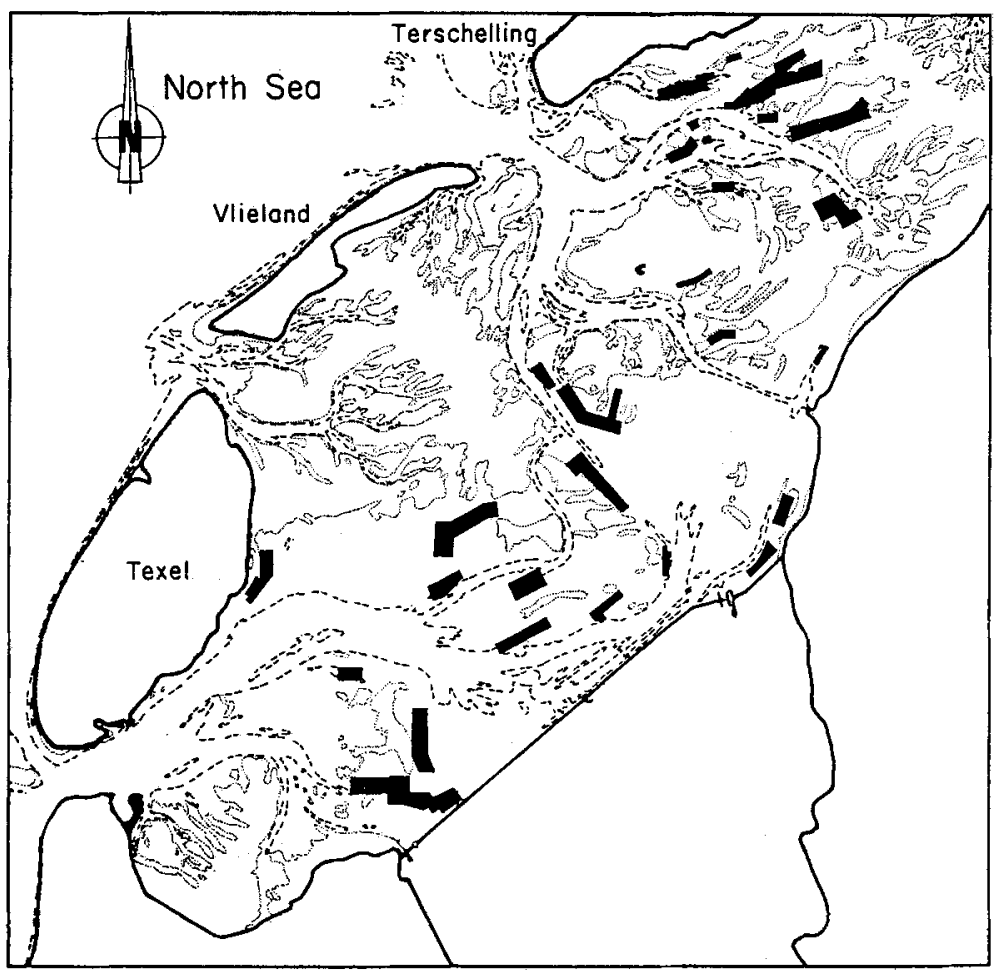

Fig. 3. Location of culture plots ( $\varpi$ ) in the sublittoral area of the western Dutch Wadden Sea in 1985 , based on information from "Direktie van de Visserijen"

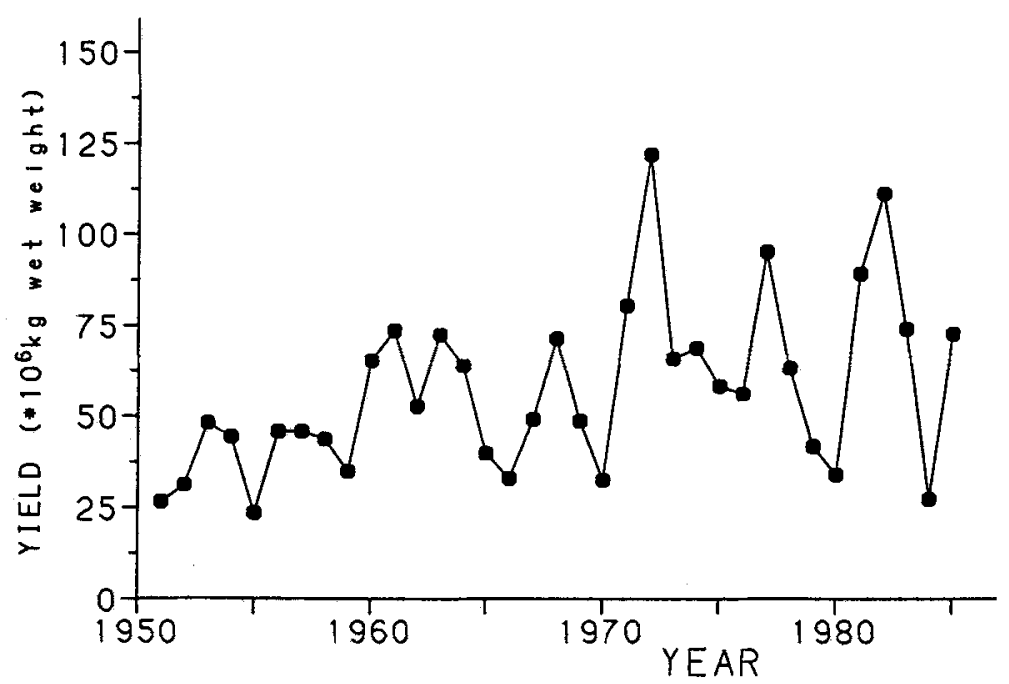

Fig. 4. Yield $\left(\times 10^{6} \mathrm{~kg}\right.$ fresh weight) of mussels from the plots in the western Dutch Wadden Sea (data from: Mosselkantoor, Bergen op Zoom) 
total area of $70 \mathrm{~km}^{2}$ ), this means a $\mathrm{P} / \mathrm{B}$ ratio of about 0.25 . Although predation by starfish and birds will form a significant loss of production, it is doubtful whether the total production of musselmeat on a plot during a season will be larger than the actual present biomass. Normally, the yield of a mussel bed is thought to be about the same as the biomass of the initial mussel seed (Dankers, 1986).

The main effect of mussel culture is the prolongation of the mean life span of the mussels, especially in the sublittoral areas. Normally, most mussel seed on wild beds is destroyed by storms in autumn or by predation. Instead, the mussel farmers collect this spat and they introduce it on the culture plots in shallow and sheltered sublittoral areas and, as a result, they positively influence its survival rate. This reduction of the mortality rate by mussel culture is illustrated by the increase of the numbers and biomass of Mytilus edulis in the western Wadden Sea between 1950 and 1980, both have enormously increased since the fifties (Table 1).

Table 1. Total biomass of mussels (tons AFDW) present in the western Wadden Sea in 1952 and 1986

\begin{tabular}{|lcc|}
\hline & 1950 & 1986 \\
& (Verweij, 1952) & (Dankers, 1986) \\
\hline Spat & 90 & \\
Middle size & 250 & \\
Consumption size & 150 & 26408 \\
Total biomass (tons AFDW) & 490 & 2640 \\
\hline
\end{tabular}

\section{DISCUSSION}

Quantitative measurements regarding primary production and benthic fauna in the western Wadden Sea started around 1970, so no long-term data are available on the state of the ecosystem in the period before and during the introduction of commercial mussel culture in the area. The only data-set available on the period 1950-1985 concerns the biomass of epi- and macrofauna on a tidal flat area near the isle of Vlieland collected by Swennen (unpubl.). However, the surface areas sampled were small $<1 \mathrm{~m}^{2}$. Both the epiand macrofauna biomass showed a similar trend over the period (Fig. 5), with a strong decrease in the sixties, low values until the mid seventies, followed by again higher values during recent years. However, this is the only long-term set available. Therefore, any reflection about the impact of mussel culture is hampered by the absence of sufficient data from the past. In this paper, the following starting points are adopted:

(1) Primary production in the western Wadden Sea showed no consistent trend between 1950 and 1960.

(2) The introduction of mussel culture between 1950 and 1960 has resulted in an increase of the mean life span of the mussel in the sublittoral area and, as a result, in larger numbers, a bigger mean size and, consequently, an increased biomass.

(3) The macrobenthic community is food-limited.

Nutrient data in the western Wadden Sea showed no trend between 1950 and 1960 and the same holds true for the loadings in the discharges of Lake IJssel. Since primary production seems to be nutrient-limited (Cadée \& Hegeman, 1974), it seems realistic to 


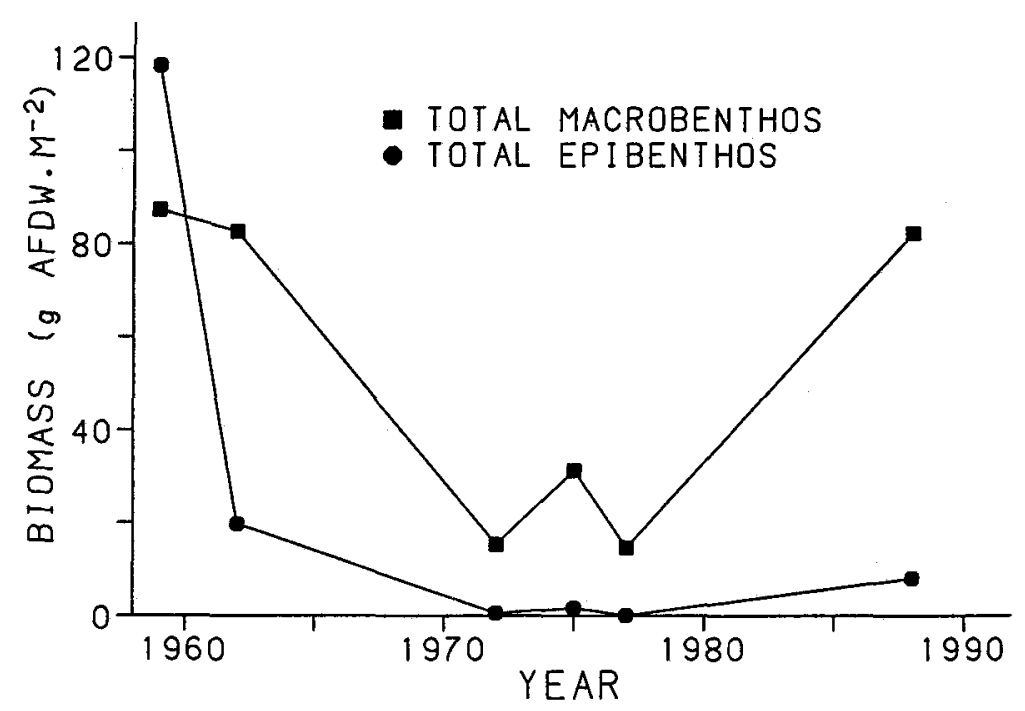

Fig. 5. Mean biomass of epi- and macrobenthos ( $\mathrm{g}$ AFDW $\mathrm{m}^{-2}$ ) at the Posthuiswad, a tidal flat area near Vlieland during the period 1958-1988 (after Swennen, unpubl.); sampling methods similar to Beukema (1974)

assume that this will also have been reflected in the primary production in the area. This would mean that the available amount of food for the intertidal and sublittoral benthic community did not show a clear trend during the period.

Farming of mussels in the sublittoral zone by a continuous removal of natural predators, i.e. starfish and crabs, reduces the natural mortality rate. Furthermore, mussels are introduced in the subtidal zone, which normally would have died rapidly in the intertidal zone. The overall effect is a considerable additional amount of biomass introduced in the sublittoral zone with a life-span of about 2-3 years.

Food limitation of the macrobenthic community is hard to prove. However, the response of the intertidal zoobenthos to eutrophication, as has been found by Beukema \& Cadée (1986), could indicate that at least in 1970, after the introduction of the mussel culture, the macrobenthos was food limited. The macrobenthos seems to react to its food supply by alterations in both growth and reproduction. Before the closure of the harbour of Den Helder, large size one-year-old mussels were only found in the harbour. On the tidal flats and in the sublittoral zone such large animals were never found. This suggests also a food limitation for the period before 1970 .

The amount of biomass additionally introduced on the mussel lots varies considerably throughout the year as a result of farming activities. Dankers et al. (1988) estimated the biomass present on the lots between 25 and 90 millions $\mathrm{kg}$ wet weight, which corresponds with 1.25 and 4.5 millions $\mathrm{kg}$ AFDW. These subtidal mussels are in a favourable position compared with animals in the intertidal zone, because they can filter continuously. In case of food competition they have an advantage and the amount of food consumed by the mussels in the sublittoral zone will reduce the remaining part of the pelagic production left for the other groups of organisms in the inter- and sublittoral. To what extent the at least partly nutrient-limited primary production will be positively 
affected by an increased nutrient regeneration from the increased pseudofaeces production is unclear. However, it is unlikely that it will balance the increased food demand of the mussels. The other food source, the benthic primary production, mainly occurring on the tidal flats, might not be affected. This is supported by the inverse relationship between yield per ha and extension of the culture during the introduction in the 1950s (Fig. 6). From the beginning onwards, this yield decreased with increasing culture area.

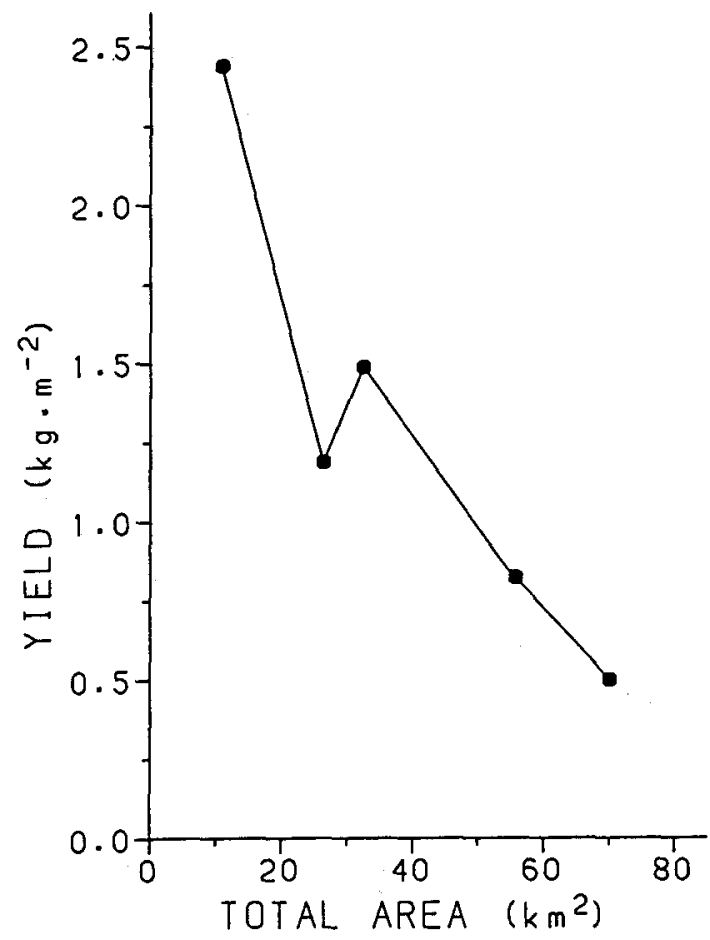

Fig. 6. Yield of consumption mussels ( $\mathrm{kg}$ fresh weight $\mathrm{m}^{-2}$ ) from the culture lots between 1950 and 1960 (data from Mosselkantoor, Bergen op Zoom) in relation to the total area of mussel culture (data from "Direktie van de Visserijen")

Such food competition will only be important when food demand is large compared with the total amount available. Due to the uncertainties in the biomass and production estimates on the lots, every calculation will depend on the basic assumptions and must be taken with caution. Instead of a calculation based on individual growth and biomass throughout the year, as has been done by Dankers (1986), it seems safer to compare overall production with the initial biomass introduced. As stated before, the $\mathrm{P} / \mathrm{B}$ ratio hardly seems to exceed 1 (Dankers et al., 1988). This production amounts to maximally 100 million $\mathrm{kg}$ fresh weight corresponding with 5 million $\mathrm{kg}$ AFDW. Assuming a food conversion efficiency of $20 \%$, this means a food intake of 25 million $\mathrm{kg}$ AFDW per year. Mussel culture takes place in an area of maximally $70 \mathrm{~km}^{2}$, compared with a surface area of the whole western Wadden Sea of $1059 \mathrm{~km}^{2}$. This means that the food supply on the 
remaining area is reduced by at least $26 \mathrm{~g} \mathrm{AFDW} \mathrm{m}^{-2}$. This value is an underestimation because the loss of biomass by predation between spat and consumption mussel is not taken into account. Moreover, large year-to-year fluctuations might be expected regarding the fluctuating yield of mussel biomass.

Intertidal biomass values in the beginning of the 1970 s amounted to about $25 \mathrm{~g}$ AFDW m ${ }^{-2}$ (Beukema, 1976). With a mean P/B ratio of 1 and a food conversion efficiency of $20 \%$, this means an annual food demand of $100 \mathrm{~g} \mathrm{AFDW} \mathrm{m}^{-2}$. Related to the $26 \mathrm{~g}$ AFDW $\mathrm{m}^{-2}$ withdrawn by the mussel culture, this suggests that mussel culture might have an impact and can be considered as a serious food competitor.

The hypothesis is postulated that after the introduction of mussel culture, which has resulted in a strong increase in biomass in the subtidal and an increased competition for food, a reduction of the intertidal macrofaunal community has occurred. Although this enlarged stock of benthic filter-feeders might have affected the primary production positively by increasing the nutrient cycling in the system, even the mussels in the sublittoral zone on the plots will be food-limited. Between 1950 and 1960, the food situation will have remained about the same. Hereafter, eutrophication started. As a result, primary production in the area increased considerably (Beukema \& Cadée, 1986; Cadée, 1986) and therefore also the available amount of food will have increased. For the intertidal macrobenthic community, a response has been observed in at least some species with higher growth rates and recruitment (Beukema \& Cadée, 1986). Less information is available on the situation in the sublittoral zone. An indication can be obtained from the annual yields of the mussel culture. These values showed enormous fluctuations due to the influence of weather conditions, market price, amount of seed available etc., apparently without any trend. However, when maximum productions are taken into consideration, which give an indication of the potential capacity, then another picture arises with increasing yields from 1970 to 1980 and thereafter a stabilization.

A second hypothesis is postulated that the eutrophication of the area has affected both the intertidal and subtidal benthic community by increasing their biomass and production. However, in the present situation food limitation still seems to occur.

One can doubt the importance of such a hypothesis if it cannot be disproven. Firstly, it stresses the importance of long-term monitoring programs. Such gradual changes in the system can only be traced after a long period. Secondly, when commercial mussel culture is introduced into other parts of the Wadden Sea, this will provide the opportunity for an independent check of this hypothesis. However, this means that every extension should be accompanied by monitoring programs already started in advance. Thirdly, it draws attention to the potentially great impact of mussel culture on the ecosystem and its potential conflict with other important functions of the system, such as being a breeding area for birds (Smit \& Wolff, 1983) and a nursery area for fish species (Zijlstra, 1972).

Acknowledgements. Thanks are due to J. J. Beukema, F. Colijn, N. Dankers, C. Swennen and J. J. Zijlstra for their critical reading of the manuscript.

\section{LITERATURE CITED}

Bennekom, A. J. van, Krijgsman-van Hartingsveld, E., Veer, G. C. M. van der Voorst, H. F. J. van, 1974. The seasonal cycle of reactive silicate and suspended diatoms in the Dutch Wadden Sea. Neth. J. Sea Res. 8, 359-374. 
Bennekom, A. J. van, Gieskes, W. W. C. \& Tijssen, S. B., 1975. Eutrophication of Dutch coastal waters. - Proc. R. Soc. (B) 189, 359-374.

Beukema, J. J., 1974. Seasonal changes in the biomass of the macrobenthos of a tidal flat in the Dutch Wadden Sea. - Neth. J. Sea Res. 8, 94-107.

Beukema, J. J., 1976. Biomass and species richness of the macrobenthic animals living on the tidal flats of the Dutch Wadden Sea. - Neth. J. Sea Res. 10, 236-261.

Beukema, J. J., 1979. Biomass and species richness of the macrobenthic animals living on a tidal flat area in the Dutch Wadden Sea: effects of a severe winter. - Neth. J. Sea Res. 13, 203-233.

Beukema, J. J., 1985. Zoobenthos survival during severe winters at high and low tidal flats in the Dutch Wadden Sea. In: Marine biology of polar regions and effects of stress on marine organisms. Ed. by J. S. Gray \& M. E. Christiansen. Wiley, Chichester, 351-361.

Beukema, J. J. \& Cadée, G. C., 1986. Zoobenthos responses to eutrophication of the Dutch Wadden Sea. - Ophelia $26,55-64$.

Beukema, J. J. \& Essink, K., 1986. Common patterns in the fluctuations of macrozoobenthic species living at different places on tidal flats in the Wadden Sea. - Hydrobiologica 142, 199-207.

Cadée, G. C., 1986. Increased phytoplankton primary production in the Marsdiep area (western Dutch Wadden Sea). - Neth. J. Sea Res. 20, 285-290.

Cadée, G. C. \& Hegeman, J., 1974. Primary production of phytoplankton in the Dutch Wadden Sea.Neth. J. Sea Res. 8, 240-259.

Dankers, N., 1986. Onderzoek naar de rol van de mossel en de mosselcultuur in de Waddenzee. Tussentijds rapport. - RIN Rapp. 86/14, 1-36.

Dankers, N., Kersting, K., Binsbergen, M. \& Zegers, K., 1986. De effecten van het stoppen van de stroming op een mosselbank. - RIN Rapp. 86/2, 1-24.

Dankers, N., Koelemay, K. \& Zeegers, K., 1988. De mossel en de mosselcultuur in de Waddenzee. RIN Rapp. (in press)

Dekker, R., 1987. The importance of the subtidal macrobenthos as a food source for the Wadden Sea ecosystem. In: Proceedings of the 5th International Wadden Sea Symposium. Ed. by S. Tougaard \& S. Asbirk, National Forest and Nature Agency \& Museum of Fishery and Shipping, Esbjerg, $27-35$.

Havinga, B., 1960. De mosselteelt in .de Waddenzee. Rapport aengeboden aan het College van Gedeputeerde Staten van de provincie Friesland, $39 \mathrm{pp}$.

Kuenen, D. J., 1942. On the distribution of mussels on the intertidal sand flats near Den Helder. Archs néerl. Zool. 6, 117-160.

Maas Geesteranus, R. A., 1942. On the formation of mussel banks by Mytilus edulis L.-Archs. néerl. Zool. 6, 283-326.

Postma, H. 1985. Eutrophication of Dutch coastal waters. - Neth. J, Zool. 35, 348-359.

Smit, C. J. \& Wolff, W. J., 1983. Birds in the Wadden Sea. In: Ecology of the Wadden Sea. Ed. by W. J. Wolff. Balkema, Rotterdam, 2, 6/1-6/308.

Veer, H. W. van der, Raaphorst,' W. van \& Bergman, M. J. N., 1989. Eutrophication of the Dutch Wadden Sea: external nutrient loadings of the Marsdiep and Vliestroom basin. - Helgoländer Meeresunters. 43, 501-515.

Verweij, J., 1952. On the ecology of distribution of cockle and mussel in the Dutch Wadden Sea, their role in sedimentation and the source of their food supply. - Archs. neer. Zool. 10, 172-239.

Verweij, J., 1954. De mossel en zijn eisen. - Faraday 24, 1-11.

Wit, J. A. W. de, Schotel, F. M. \& Bekkers, L. E. J., 1982. De waterkwaliteit van de Waddenzee. RIZA nota 82-065, 1-67.

Zijlstra, J. J., 1972. On the importance of the Waddensea as a nursery area in relation to the conservation of the southern North Sea fishery resources. - Symp. zool. Soc. London 29, 233-258.

Zimmerman, J. T. F., 1976. Mixing and flushing of tidal embayments in the western Dutch Wadden Sea. Part I. Distribution of salinity and calculation of mixing time scales. - Neth. J. Sea Res. 10, $149-191$ 